\title{
The western black crested gibbon Nomascus concolor in Laos: new records and conservation status
}

\author{
Arlyne Johnson, Sarinda Singh, Malaykham Duangdala and Michael Hedemark
}

\begin{abstract}
Few viable populations of western black crested gibbon Nomascus concolor remain in southern China and northern Indochina, where the species is endemic. We conducted village surveys in the Nam Ha National Protected Area in Luang Namtha Province, Lao PDR to assess presence and status of gibbon populations. Forest surveys used to verify gibbon presence and species identification confirmed village reports of gibbon populations in three locations, and sonogram analysis identified all as $N$. concolor. These represent an expansion in the known distribution of western black crested gibbon in Lao PDR and the only known populations to occur inside the national protected area system.
\end{abstract}

Significantly longer times since gibbons were last reported were associated with villages with $<50 \%$ forest cover and high human populations. Although village taboos regarding gibbon hunting were reported, hunting and trade were nevertheless identified as factors contributing to gibbon decline. Results indicated that increased community-based management, public education and enforcement are needed to maintain $N$. concolor populations and their habitat in Lao PDR.

Keywords Hylobatidae, Lao PDR, Nam Ha National Protected Area, Nomascus concolor, western black crested gibbon.

\section{Introduction}

Crested gibbons of the genus Nomascus (family Hylobatidae) are found only in Indochina and southern China (Geissmann, 2002). Although Chinese literature from 1,000 years ago reported gibbons as far north as the Yellow River, increasing human population and consequent hunting and land use in tropical forests have led to a decline of gibbon populations (MacKinnon \& MacKinnon, 1987; Bleisch \& Chen, 1990; Eames \& Robson, 1993; Brockelman, 1994; Duckworth et al., 1995; Geissmann, 2003). Of the three crested gibbon species found in Lao PDR the western black crested gibbon Nomascus concolor is of international conservation significance and requires urgent management attention (Duckworth et al., 1999; Geissmann et al., 2000). This species is categorized as Endangered on the IUCN Red List (IUCN, 2004) and is the fourth most threatened gibbon species (Geissmann, 2003). It is known only from Lao PDR, Vietnam and China, with approximately 54 groups remaining in northern Vietnam (La Quang Trung et al., 2002) and 2,000 individuals in southern China (Bleisch \& Jiang, 2000).

Arlyne Johnson (Corresponding author) Wildlife Conservation Society, Box 6712, Vientiane, Lao PDR. E-mail ajohnson@wcs.org

Sarinda Singh, Malaykham Duangdala and Michael Hedemark Wildlife Conservation Society-Lao PDR Program, Box 6712, Vientiane, Lao PDR.

Received 27 April 2004. Revision requested 25 August 2004. Accepted 17 December 2004.
Populations of N. concolor in Lao PDR appear to be completely isolated from those in Vietnam and China (Geissmann et al., 2000), although relatively little is known about their status (Duckworth et al., 1999). Recent records exist only from a small area in Bokeo province (Fig. 1) where black crested gibbon populations were thought to be surrounded by populations of the more widely distributed white-cheeked crested gibbon Nomascus leucogenys (Geissmann et al., 2000). Surveys in Bokeo province identified nine gibbon groups in $20 \mathrm{~km}^{2}$ of the Nam Kan valley in the Nam Kan Provincial Protected Area in 1999. Lying north-east of the Nam Kan, the Nam Ha National Protected Area in Luang Namtha Province was once reported to support gibbon populations of an undetermined species (Tizard et al., 1997). Populations were considered extirpated by hunting (Duckworth et al., 1999) until recent village accounts reported gibbons (Hedemark \& Vongsak, 2003). Given the geographic isolation of $N$. concolor in north-western Lao PDR, surveys to identify additional populations were identified as a high conservation priority (Duckworth et al., 1999).

Although gibbons are legally protected in Lao PDR (MAF, 2003), their sale as pets or for medicine persists (Duckworth et al., 1999; Nooren \& Claridge, 2001). Their bones are used to treat rheumatism in neighbouring China (Bleisch \& Chen, 1990). Awareness and enforcement of laws protecting gibbons are limited due to lack of government funding, trained personnel, and conservation infrastructure (Duckworth et al., 1995). Reports (Duckworth et al., 1999) from the Nam Kan 

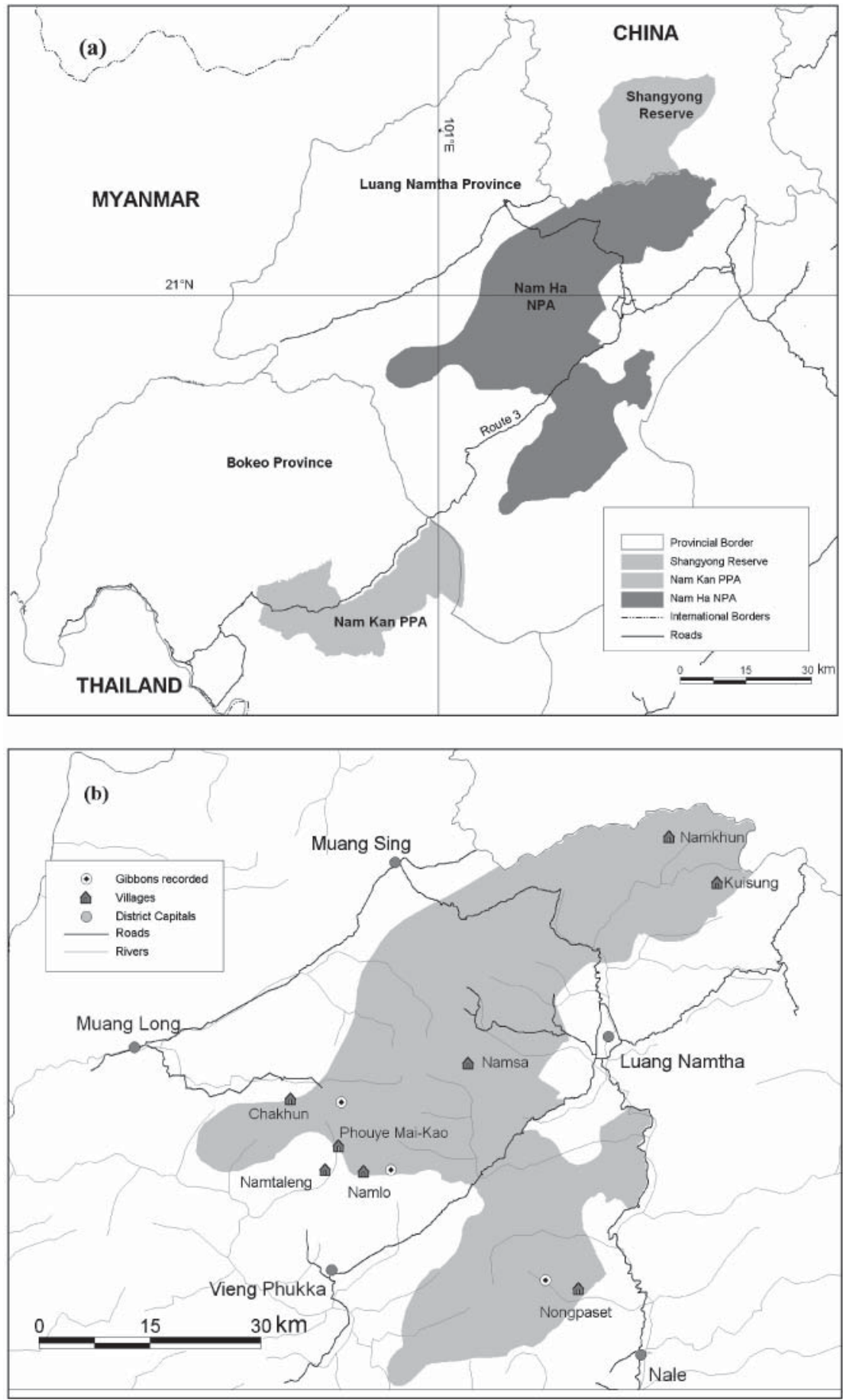

Fig. 1 (a) Locations of the Nam Ha National Protected Area (NPA), Luang Namtha province and the Nam Kan Provincial Protected Area (PPA), Bokeo Province, in northern Lao PDR. (b) Location of villages surveyed and areas where gibbons were recorded in the Nam Ha National Protected Area.

Provincial Protected Area suggested that gibbons persisted there because of village taboos against hunting them, but it was not known if such beliefs underpinned the recent accounts of remaining gibbon populations in the National Protected Area.

To address these questions we conducted a survey in the Nam Ha National Protected Area to determine (1) if gibbons were still present and (2), if so, which species and its status, and (3) to determine if village rules existed to govern the use of gibbons and, if so, how this may influence their conservation.

\section{Study area}

Surveys were conducted in the Nam Ha National Protected Area from January to March 2003 in response 
to village reports that gibbons were most often heard during these months (Hedemark \& Vongsak, 2003). The Protected Area covers 222,000 hectares of subtropical broadleaf evergreen forest at 560-2,094 $\mathrm{m}$ altitude (Rundel, 1999). Dominant plant species at lower elevations are Terminalia myricarpa (Combretaceae) and Pometia tomentosa (Sapindaceae) with Fagacaeae dominating the montane forest canopy at higher elevations. Thirty-two percent of the Protected Area's landcover is medium crown density forest with the remainder a mosaic of shrubland and forest patches altered by human use (MRC, 2001; Hedemark, 2003). There are 41 villages in and near the Protected Area (largely Tibeto-Burman, Hmong-Mien and Mon-Khmer ethnic groups; Anon., 2000) whose principle area of natural resource use is within the Protected Area. Provincial population density is 14 persons $\mathrm{km}^{-2}$, growing at an annual rate of $2.5 \%$ (National Statistics Center, 2000).

\section{Methods}

Surveys were carried out in eight villages (Fig. 1) of Akha, Mien, Khamu and Kui ethnicity that reported gibbons in the recent past (Tizard et al., 1997; Hedemark \& Vongsak, 2003). Semi-structured interviews (Byers, 1996) were conducted with individual hunters and hunter groups, identified by the village headman, about presence, status and management of primates. Questions were asked about 10 primate species, including $N$. concolor and N. leucogenys, with pictures used to confirm identification.

Variation in reports of gibbon observations across different village areas was examined in relation to human population and forest cover using mapping (MRC, 2001) of land cover that classified vegetation into forest and non-forest categories. This was overlain onto a map with a $5 \mathrm{~km}$ radius buffer drawn around each village using the Geographical Information System ArcView (ESRI, Redlands, USA). Villages were classified as forest if $\geq 50 \%$ or more of the buffer area included forest vegetation, otherwise they were classed as non-forest.

When village surveys suggested gibbons were present, forest surveys were made in identified locations to confirm species presence and identity by recording gibbon vocalizations (Geissmann \& Thanh, 2001). The songs of
$N$. concolor and N. leucogenys are distinguishable by sonogram analysis (Geissmann, 1995). Two survey teams recorded all vocalizations heard during 05.30-09.00 from listening stations on ridge tops separated by several hundred metres (Brockelman \& Ali, 1987). Locations (using a Global Positioning System) of each station and compass bearings of vocalizations were recorded. A minute-byminute record of song duration was made, and weather recorded every 15 minutes following a standardized coding system. Locations of gibbon groups that were heard by both teams were estimated by triangulation. Tape recordings were digitized using Sound Recorder (Microsoft, Redmond, USA) and sonograms created with Sound Forge (Sonic Foundry, Madison, USA).

\section{Results}

\section{Village surveys}

Sixty-four hunters, with an average age of 37 (range 17-70) years, were interviewed in eight villages. Eightysix percent reported hunting year-round and on average 3.2 times per week, thus representing a relatively constant and frequent presence in the forest. As the information obtained from the interviews was nearly identical for N. concolor and N. leucogenys (Table 1) and as in our forest surveys (see below) we only found $N$. concolor, further analysis is for this species only (Naughton-Treves et al., 2003). Forty-four percent of hunters reported observations of gibbons and $16 \%$ had sighted gibbons. When sighted, gibbons were consistently reported as $1-5$ individuals, corresponding to their maintenance of small family groups (Leighton, 1987; Bleisch \& Chen, 1991). No young were reported. There were reports of gibbons from four villages (Table 2). In two other villages (Namsa and Kuisung) gibbons were reported as occurring in the area 10 or more years earlier but not since, indicating possible local extirpations.

Time since gibbons were last seen by individual hunters was significantly and positively correlated with village population (Spearman's rank correlation $r_{s}=0.31$, $n=64, \mathrm{P}<0.05$ ). Time since gibbons were last seen was also significantly related to forest cover, with a longer time reported by individual hunters in villages classified as non-forest (Mann-Whitney $\mathrm{Z}=-2.06$, $n=64, \mathrm{P}<0.05)$. Mean village population was higher in

Table 1 Summary of information collected about N. concolor and N. leucogenys during interviews with individual hunters $(n=64)$.

\begin{tabular}{|c|c|c|c|c|c|c|c|c|c|}
\hline \multirow[b]{2}{*}{ Species } & \multirow{2}{*}{$\begin{array}{l}\text { Ever } \\
\text { observed }\end{array}$} & \multicolumn{3}{|c|}{ Years since last observed } & \multirow{2}{*}{$\begin{array}{l}\text { Ever } \\
\text { seen }\end{array}$} & \multicolumn{3}{|c|}{ No. seen } & \multirow{2}{*}{$\begin{array}{l}\text { Ever seen } \\
\text { young }\end{array}$} \\
\hline & & Min. & Max. & Avg. & & Min. & Max. & Avg. & \\
\hline N. concolor & $44 \%$ & 0.05 & 35 & 6.5 & $16 \%$ & 1 & 5 & 2.2 & 0 \\
\hline N. leucogenys & $45 \%$ & 0.05 & 30 & 6.3 & $16 \%$ & 1 & 3 & 1.8 & 0 \\
\hline
\end{tabular}


Table 2 Responses by groups of hunters regarding N. concolor population trends in eight villages (Fig. 1b).

\begin{tabular}{lll}
\hline Village (no. in group) & $\begin{array}{l}\text { Estimated } \\
\text { abundance }\end{array}$ & $\begin{array}{l}\text { Changes in } \\
\text { abundance }\end{array}$ \\
\hline Chakhun (6) & Few & $\begin{array}{l}\text { Decreasing } \\
\text { Decreasing }\end{array}$ \\
Kuisung (8) & Absent & Stable \\
Namkhun (6) & Absent & Decreasing \\
Namlo (5) & Few & Stable \\
Namsaleng (4) & Absent & Stable \\
Nongpaset (9) & Absent & \\
Phouye Mai-Kao (11) & Few & Few \\
\hline
\end{tabular}

non-forest compared to forest villages but the difference was not significant (Mann-Whitney $\mathrm{Z}=0.30, \mathrm{n}=8$, $\mathrm{P}>0.05)$. In contrast, significantly more individual hunters reported observations of gibbons from nonforest than forest villages $\left(\chi^{2}=0.25, n=64, \mathrm{P}<0.05\right)$.

In estimates of abundance by hunter groups, gibbons were consistently reported as either few in number or absent, and were considered to be declining in four of the villages (Table 2). When hunter groups were asked for possible explanations for the observed changes in abundance, all responses related declines to human activities, the most frequently cited being shifting cultivation and hunting (100\% and $88 \%$ of villages, respectively).

Taboos governing gibbon hunting were reported in $88 \%$ of villages. The most commonly reported restriction was the belief that gibbons were spirits and that hunting them would result in illness or death of the hunter or other people in the village. Despite the reported taboos, hunters repeatedly stated the need for regulations to control gibbon hunting, citing this as a major factor in gibbon decline.

\section{Forest surveys}

Forest surveys were conducted from listening stations in three areas (Fig. 1). Stations were at $679-1535 \mathrm{~m}$ altitude, with gibbons heard on five out of the 12 mornings surveyed (Table 3). Gibbons were recorded between 6.32 and 8.26 a.m. with an average song bout of 11 (range $2-22)$ minutes. Gibbons were only heard singing in the absence of rain, when cloud cover was $<50 \%$ and it was not windy. Triangulation indicated that a minimum of five different gibbon groups were heard from the listening stations: one west of Nongpaset, two east of Chakhun, and two east of Namlo. All sonograms matched those of $N$. concolor (Geissmann, 1995). It was not possible to separate subspecies (N. c. concolor, N. c. furvogaster, N. c. jingdongensis and N. c. lu, with the latter previously identified as occurring in north-west Lao PDR; Brandon-Jones et al., 2004) from the vocalizations (T. Geissmann, pers. comm.).

\section{Discussion}

This study provides new evidence that the distribution of western black crested gibbon in Lao PDR extends into the Nam Ha National Protected Area in at least three locations, c. $50 \mathrm{~km}$ north-east of where the species was previously recorded in the Nam Kan valley (Geissmann et al., 2000). Although this was not a comprehensive survey of the Protected Area and results from village and forest

Table 3 Forest survey effort in three areas (Fig. 1b), with dates and timings of vocalizations recorded.

\begin{tabular}{|c|c|c|c|c|c|c|c|c|c|c|}
\hline \multirow[b]{2}{*}{ Survey area } & \multicolumn{2}{|c|}{ Survey effort } & \multirow[b]{2}{*}{$\begin{array}{l}\text { Vocalizations } \\
\text { recorded }\end{array}$} & \multirow[b]{2}{*}{$\begin{array}{l}\text { Survey } \\
\text { team }\end{array}$} & \multicolumn{3}{|c|}{ Gibbon group 1} & \multicolumn{3}{|c|}{ Gibbon group 2} \\
\hline & $\begin{array}{l}\text { Survey } \\
\text { period }\end{array}$ & $\begin{array}{l}\text { Avg. } \\
\text { hours } \\
\text { per team }\end{array}$ & & & $\begin{array}{l}\text { Time } \\
\text { start }\end{array}$ & $\begin{array}{l}\text { Time } \\
\text { end }\end{array}$ & $\begin{array}{l}\text { Song } \\
\text { bout } \\
\text { (mins) }\end{array}$ & $\begin{array}{l}\text { Time } \\
\text { start }\end{array}$ & $\begin{array}{l}\text { Time } \\
\text { end }\end{array}$ & $\begin{array}{l}\text { Song } \\
\text { bout } \\
\text { (mins) }\end{array}$ \\
\hline \multirow[t]{3}{*}{ Nongpaset } & 3-6 Feb. & 13.2 & 4 Feb. & 1 & $06: 57$ & 07:00 & 4 & & & \\
\hline & & & & 2 & 07:00 & 07:01 & 2 & & & \\
\hline & & & & & $07: 15$ & $07: 18$ & 4 & & & \\
\hline \multirow{10}{*}{$\begin{array}{l}\text { Chakhun/Phouye } \\
\text { Mai-Kao }\end{array}$} & 14-18 Feb. & 18.2 & 18 Feb. & 1 & $06: 43$ & 07:04 & 22 & $07: 50$ & $08: 12$ & 22 \\
\hline & & & & & $07: 37$ & $07: 42$ & 6 & & & \\
\hline & & & & 2 & $06: 43$ & 07:04 & 22 & 07:51 & $08: 12$ & 21 \\
\hline & & & & & $07: 37$ & $07: 42$ & 6 & & & \\
\hline & & & & & 08:19 & $08: 26$ & 8 & & & \\
\hline & 27-28 Feb. & 7.1 & $27 \mathrm{Feb}$. & 1 & $06: 49$ & $06: 57$ & 9 & & & \\
\hline & & & 28 Feb. & 1 & $06: 32$ & $06: 38$ & 7 & & & \\
\hline & & & & & 07:07 & 07:20 & 14 & & & \\
\hline & & & & 2 & $06: 33$ & $06: 41$ & 9 & & & \\
\hline & & & & & $07: 10$ & $07: 21$ & 12 & & & \\
\hline Namlo & 3 Mar. & 3.7 & 3 Mar. & 1 & $06: 33$ & $06: 51$ & 19 & $06: 36$ & $06: 39$ & 3 \\
\hline
\end{tabular}


surveys provided no direct measure of abundance, it appears that the number of gibbon groups in the Protected Area is low.

Although all sonograms of gibbon recordings matched that of $N$. concolor, both $N$. concolor and $N$. leucogenys were reported in the village surveys, and the data obtained from interviews with individual hunters (Table 1) was nearly identical for both species. These results indicate that responses by hunters alone were not sufficient to identify which species were present. It is likely that responses were influenced by the difficulty of sighting, and thus distinguishing, the species, as is commonly the case where gibbons are hunted and wary (Bleisch \& Chen, 1991). N. concolor and N. leucogenys are not known to be sympatric in Lao PDR (Geissmann et al., 2000), but our results and records of $N$. leucogenys from adjoining Shanyong Reserve, China (Bleisch \& Chen, 1990), suggest that the boundary between the two species could lie within the Protected Area.

Information from hunters on gibbon presence and location proved to be reliable. In every village where gibbons were reportedly present and forest surveys conducted, gibbons were heard. While local knowledge was valuable in defining the presence and location of gibbons, it was less useful for species identification, a frequently reported problem when comparing local and scientific taxonomies (Berlin et al., 1966; Evans et al., 2001).

Higher village populations and non-forest cover were significantly associated with longer times since gibbons were last reported, and 83\% of households in and around the Protected Area engage in shifting cultivation for hill rice production (Thanpavong et al., in press). Dependence on shifting cultivation coupled with growing human population is contributing to an expansion of agricultural activities into the forest, thus leading to habitat loss as well as an increased likelihood of opportunistic hunters encountering gibbon populations.

While gibbons generally prefer old-growth forest habitat (Leighton, 1987; Rowe, 1996), they are known to persist in degraded habitats in the absence of hunting (Duckworth, 1996). This suggests that forest cover in the Protected Area (32\% relatively undisturbed and the remainder a mosaic of forest patches) is probably not the main factor causing the reported decline in gibbon numbers. Hunting in the Protected Area is largely opportunistic, occurring in forested areas near hill rice fields during periods of field preparation and harvest (Johnson et al., 2003). Hunting is widely practised and a common component of rural livelihoods. Guns are kept in fields and commonly used for capturing large $(>2 \mathrm{~kg})$ and arboreal animals. Subsistence is focused on consumption of smaller animals, whereas wildlife used for medicine is more frequently traded, with c. $33 \%$ of households reporting wildlife buyers coming to their village.
Increased contact between opportunistic hunters and gibbon populations, combined with the demand for gibbons as pets and medicine and the access of wildlife buyers to villages probably provides sufficient incentive for villages to hunt gibbons. Hence, village reports from the Protected Area are consistent with observations in southern China (Bleisch \& Chen, 1990) that the combination of deforestation and hunting are the main threats to N. concolor.

Although more observations of gibbons were reported from non-forest than forest villages, this may be a result of the concentration of gibbon populations in small forest patches within a fragmented landscape. Ease of observing gibbons may increase when they are concentrated into smaller forest areas (Bleisch \& Chen, 1990), although the viability of populations in such situations is probably limited (Peres, 2001).

Taboos on gibbon hunting corresponded with reports (Duckworth et al., 1999) from the Nam Kan area, although there was no evidence of active communitybased management of gibbon populations such as demarcation and protection of forests where gibbons live. The apparently contradictory opinion of villagers that hunting is the main cause of gibbon decline would need to be considered in any community participation in the protection of gibbon populations, a priority action identified by a recent international symposium on gibbon conservation (Geissmann, 2003). Our results suggest that the presence of taboos is probably important but not sufficient as a conservation strategy. Undisturbed forests beyond the boundaries of village agricultural areas, and with relatively low human populations, probably have the greatest potential for conserving gibbon populations and should be prioritized for protection. Approximately $38 \%$ of the Protected Area is $>5 \mathrm{~km}$ from a road or village (Hedemark, 2003) and coincides with areas where gibbons were found in this study.

The key factors for successful conservation of Nomascus concolor will be (1) elimination of hunting and trade, (2) engagement of the public by raising awareness, (3) protection and linking of remaining gibbon habitat, and (4) comprehensive assessment of gibbon distribution and abundance.

1) Elimination of hunting and trade Given the joint role of villages and government in management of the Protected Area (MAF, 2003), engaging the cooperation of both will be critical to gibbon survival. To facilitate this the Luang Namtha provincial governor (Emergency Order 02/17 Feb 2004) set unprecedented fines for wildlife trade and provided for gun control, which if enforced could reduce opportunistic hunting of gibbons. Lao PDR is one of the fastest growing tourism destinations in the world, with wildlife viewing a top priority for international visitors (World Tourism Organisation, 2001, 2002), and with 
Nam Ha identified as the country's first ASEAN Heritage Park. This could provide an opportunity for government and international agencies to actively promote ecotourism benefits to villages where gibbons persist in return for increased hunter collaboration in gibbon protection.

2) Engagement of the public by raising awareness Conservation extension should target villages and appropriate government authorities to raise awareness of the status, ecology and economic and cultural importance of the gibbon.

3) Protection and linking of remaining gibbon habitat The Chakhun and Nongpaset populations are located in a core zone of the Protected Area, where shifting cultivation and hunting are not allowed (MAF, 2003), whereas the populations near Namlo are outside the Protected Area. The Nongpaset population is completely separated from the others by Route 3 (Fig. 1), which is being upgraded to a major economic corridor linking China and Thailand (Asian Development Bank, 2002) and where the forest is highly fragmented by human use (Marris et al., 2002). The area that could link N. concolor populations in Nam Ha with those in Nam Kan is dominated by degraded forest (MRC, 2001). Suitable forest habitat should not therefore be felled or further isolated (Bleisch \& Chen, 1990; Geissmann et al., 2000) and the boundaries of the Protected Area should be amended to include the gibbon populations near Namlo.

4) Comprehensive assessment of distribution and abundance Given that gibbons sing less in areas where they are heavily hunted (Brockelman \& Srikosamatara, 1993), it is possible there are other groups or populations in the Protected Area that are small or difficult to detect. Village reports that both $N$. concolor and N. leucogenys occur in the area necessitate more extensive forest surveys. Methods for estimating gibbon abundance (Brockelman \& Srikosamatara, 1993) will need to be used to estimate gibbon distribution and density in and around the Protected Area.

The status of the N. concolor is of great concern (Geissmann, 2003). Our results indicate that the distribution of the species in Lao PDR is greater than previously thought and that they continue to persist in one of the country's national protected areas. Given the continued threat to the species these new records do not, however, warrant a change in their categorization as Endangered (IUCN, 2004).

In response to results from this study, the national Forestry Department and the Luang Namtha provincial forestry office, with support from the Wildlife Conservation Society - Lao PDR Program, are currently working with villages near gibbon populations in the Nam Ha National Protected Area to demarcate and protect core zones and raise public awareness for gibbon conservation.

\section{Acknowledgements}

We thank Nam Ha National Protected Area (Phimkeo Thamlasine, Outhai Vongsa, Chukavanh Thammavong, Ae Saymany and Bounma Sibunhuang) for facilitating the study. Research collaborators included Thavy Phimminith, Buasavanh Chanthasone, and Tynoi Namsombath (Faculty of Forestry, National University of Laos) and Khamkhoune Khounboline (Forestry Department). We thank William Duckworth, Anouchka Nettelbeck, Madhu Rao, Bryan Stuart and two anonymous reviewers for their comments, and Dr Thomas Geissmann, University Zurich-Irchel, Switzerland for reviewing tape recordings and recording methods. We thank the Wildlife Conservation Society - Lao PDR and Asia Programs for logistical assistance. Funding was generously provided by the United States Fish and Wildlife Service, Great Ape Conservation Fund (No. 98210-1-G287).

\section{References}

Anonymous (2000) Lao Geographic Atlas. The Vietnam Research Institute of Land Administration and The Lao National Geographic Department, Vientiane, Lao PDR.

Asian Development Bank (2002) Greater Mekong Subregion: Northern Economic Corridor Project. Http:/ / www.adb.org/ Documents/ADBBO/LOAN/34231013.ASP\#description [accessed 09 October 2003].

Berlin, B., Breedlove, D.E. \& Raven, P.H. (1966) Folk taxonomies and biological classification. Science, 154, 273-275.

Bleisch, W. \& Chen, N. (1990) Conservation of the black-crested gibbon in China. Oryx, 24, 147-156.

Bleisch, W.V. \& Chen, N. (1991) Ecology and behavior of wild black-crested gibbons (Hylobates concolor) in China with a reconsideration of evidence for polygyny. Primates, 32, 539-548.

Bleisch, W. \& Jiang, X.L. (2000) Action Plan for Conservation of Gibbons of the Wuliang Mountains. Unpublished Report. Sino-Dutch Forest Conservation and Community Development Project, Kunming, China.

Brandon-Jones, D., Eudey, A.A., Geissmann, T., Groves, C.P., Mlenick, D.J., Morales, J.C., Shekelle, M. \& Stewart, C.-B. (2004) Asian primate classification. International Journal of Primatology, 25, 97-164.

Brockelman, W.Y. (1994) Thai gibbon population and habitat viability analysis. Asian Primates, 4, 1-2.

Brockelman, W.Y. \& Ali, R. (1987) Methods of surveying and sampling forest primate populations. In Primate Conservation in Tropical Rainforest (eds C.W. Marsh \& R.A. Mittermeier), pp. 23-62. Liss, New York, USA.

Brockelman, W.Y. \& Srikosamatara, S. (1993) Estimation of density of gibbon groups by use of loud songs. American Journal of Primatology, 29, 93-108. 
Byers, B.A. (1996) Understanding and Influencing Behaviors in Conservation and Natural Resources Management. Biodiversity Support Program, Washington, DC, USA.

Duckworth, J.W. (1996) Bird and mammal records from the Sangthong District, Vientiane Municipality, Laos, in 1996. Natural History Bulletin of the Siam Society, 44, 217-242.

Duckworth, J.W., Salter, R.E. \& Khounboline, K. (compilers) (1999) Wildlife in Lao PDR: 1999 Status Report. IUCN, Wildlife Conservation Society and Centre for Protected Areas and Watershed Management, Vientiane, Lao PDR.

Duckworth, J.W., Timmins, R.J.G., Anderson, Q.A., Thewlis, R.M., Nemeth, E., Evans, T.D., Dvorak, M. \& Cozza, K.E.A. (1995) Notes on the status and conservation of the gibbon Hylobates (Nomascus) gabriellae in Laos. Tropical Biodiversity, 3, 15-27.

Eames, J.C. \& Robson, C.R. (1993) Threatened primates in southern Vietnam. Oryx, 27, 146-154.

Evans, T.D., Segdala, K., Viengkham, O.V. \& Thammavong, B. (2001) A Field Guide to the Rattans of Lao PDR. Royal Botanic Garden Kew /Forestry Research Centre/Oxford Forestry Institute/Darwin Initiative, Oxford, UK.

Geissmann, T. (1995) Gibbon systematics and species identification. International Zoo News, 42, 467-501.

Geissmann, T. (2002) Taxonomy and evolution of gibbons. Evolutionary Anthropology, Suppl. 1, 28-31.

Geissmann, T. (2003) Symposium on gibbon diversity and conservation: concluding resolution. Asian Primates, 8, $28-29$.

Geissmann, T., Dang, N.X., Lormee, N. \& Momberg, F. (2000) Vietnam Primate Conservation Status Review 2000 - Part 1: Gibbons. Fauna \& Flora International Indochina Programme, Hanoi, Vietnam.

Geissmann, T., Nguyen Xuan Dang, Lormée, N. \& Momberg, F. (2003) Status review of gibbons in Vietnam. Asian Primates, 8, $10-12$.

Geissmann, T. \& Thanh, V.N. (2001) Preliminary results of a primate survey in northeastern Vietnam, with special reference to gibbons. Asian Primates, 7, 1-4.

Hedemark, M. (2003) Forest Survey of the Nam Ha National Protected Area. Wildlife Conservation Society, Vientiane, Lao PDR.

Hedemark, M. \& Vongsak, U. (2003) Wildlife Survey of the Nam Ha National Protected Area. Wildlife Conservation Society, Vientiane, Lao PDR.

IUCN (2004) 2004 IUCN Red List of Threatened Species. Http:/ / www.redlist.org [accessed 3 May 2005].

Johnson, A., Singh, S., Dongdala, M. \& Vongsa, O. (2003) Wildlife Hunting and Use in the Nam Ha National Protected Area, Lao PDR: Implications for Rural Livelihoods and Biodiversity Conservation. Wildlife Conservation Society, Vientiane, Lao PDR.

La Quang Trung, Trinh Dinh Hoang, Long, B. \& Geissmann, T. (2002) Status review of black crested gibbons (Nomascus concolor and Nomascus sp. cf. nasutus) in Vietnam. In Caring for Primates. Abstracts of the XIXth Congress of the International Primatological Society, 4th-9th August 2002, Beijing, China, pp. 131-132. Mammalogical Society of China, Beijing, China.

Leighton, D.R. (1987) Gibbons: territoriality and monogamy. In Primate Societies (eds B.B. Smuts, D.L. Cheney, R.M. Seyfarth, R.W. Wrangham \& T.T. Struhsaker), pp. 135-145. The University of Chicago Press, Chicago, USA.

MAF (Ministry of Agriculture and Forestry) (2003) National Biodiversity Conservation Areas, Aquatic and Wildlife Management Regulations. No. 0360/AF.2003. Ministry of Agriculture and Forestry, Vientiane, Lao PDR.
MacKinnon, J. \& MacKinnon, K. (1987) Conservation status of the primates of the Indo-Chinese subregion. Primate Conservation, 8, 187-195.

Marris, G., Hedemark, M., Johnson, A. \& Vongkhamheng, C. (2002) Environmental Baseline Study of the Route 3 Upgrade Through the Nam Ha National Protected Area. Unpublished Report. Wildlife Conservation Society, Vientiane, Lao PDR.

MRCS (Mekong River Commission) (2001) Forest Cover Monitoring Project. Mekong River Commission, Phnom Penh, Cambodia.

National Statistics Center (2000) Basic Statistics of the Lao PDR 1975-2000. State Planning Committee, National Statistics Center, Vientiane, Lao PDR.

Naughton-Treves, L., Mena, J.L., Treves, A., Alvarez, N. \& Radeloff, V.C. (2003) Wildlife survival beyond park boundaries: the impact of slash-and-burn agriculture and hunting on mammals in Tambopata, Peru. Conservation Biology, 17, 1106-1117.

Nooren, H. \& Claridge, G. (2001) Wildife Trade in Laos: The End of the Game. Netherlands Committee for IUCN, Amsterdam, The Netherlands.

Peres, C.A. (2001) Synergistic effects of subsistence hunting and habitat fragmentation on Amazonian forest vertebrates. Conservation Biology, 15, 1490-1505.

Rowe, N. (1996) The Pictorial Guide to the Living Primates. Pogonias Press, New York, USA.

Rundel, P.W. (1999) Forest Habitat and Flora in Lao PDR, Cambodia and Vietnam. Conservation Priorities in Indochina. World Wildlife Fund, Indochina Programme Office, Hanoi, Vietnam

Thanpavong, B., Savattvong, S., Holmgren, V. \& Meyer, G. (in press) Biodiversity Country Report - Lao PDR. Ministry of Agriculture and Forestry and Science, Technology and Environment Agency, Vientiane, Lao PDR.

Tizard, R., Davidson, P., Khounboline, K. \& Salivong, K. (1997) A Wildlife and Habitat Survey of Nam Ha and Nam Kong Protected Areas, Luang Namtha Province, Lao PDR. Wildlife Conservation Society, Vientiane, Lao PDR.

World Tourism Organization (2001) Tourism Market Trends Asia, 2001 Edition. World Tourism Organization, Madrid, Spain.

World Tourism Organization (2002) Tourism Market Trends 2002 - World Overview and Tourism Topics. World Tourism Organization, Madrid, Spain.

\section{Biographical sketches}

Arlyne Johnson has studied approaches to communitybased management of wildlife hunting and trade, and human-wildlife conflict in the Neotropics, Melanesia, and most recently in south-east Asia.

Sarinda Singh is currently studying socio-cultural aspects of wildlife use in Lao PDR, and previously worked on projects evaluating performance of protected area management in Australia.

Malaykham Duangdala is a forester and research assistant on wildlife hunting and trade studies in Lao PDR.

Michael Hedemark has worked on biodiversity monitoring in Amazonian Ecuador, Papua New Guinea and Lao PDR using information management and GIS landscape analysis to guide natural resource management and land use planning. 